\title{
Soil respiration of a Moso bamboo forest significantly affected by gross ecosystem productivity and leaf area index in an extreme drought event
}

Yuli Liu 1,2,3 , Guomo Zhou Corresp., 1,2,3 , Huaqiang Du Corresp.., 1,2,3 , Frank Berninger ${ }^{2,4}$ ，Fangjie Mao ${ }^{1,2,3}$, Xuejian Li ${ }_{1,2,3}$, Liang Chen ${ }^{1,2,3}$, Lu Cui ${ }^{1,2,3}$, Yangguang Li ${ }^{1,2,3}$, Di'en Zhu ${ }^{1,2,3}$

${ }^{1}$ State Key Laboratory of Subtropical Silviculture, Zhejiang Agricultural and Forestry University, Hangzhou,Lin'an, Zhejiang province, China

${ }^{2}$ Key Laboratory of Carbon Cycling in Forest Ecosystems and Carbon Sequestration of Zhejiang Province, Zhejiang Agricultural and Forestry University, Hangzhou,Lin'an, Zhejiang province, China

4 Department of Forest Ecology, University of Helsinki, Helsinki, Finland

Corresponding Authors: Guomo Zhou, Huaqiang Du

Email address: zhougm@zafu.edu.cn, dhqrs@126.com

Moso bamboo has large potential to alleviate global warming through carbon sequestration. Since soil respiration (Rs) is a major source of $\mathrm{CO} 2$ emissions, we analyzed the dynamics of soil respiration (Rs) and its relation to environmental factors in a Moso bamboo (Phllostachys heterocycla cv. pubescens) forest to identify the relative importance of biotic and abiotic drivers of respiration. Annual average Rs was 44.07 t CO2 ha-1 a-1. Rs correlated significantly with soil temperature $(P<0.01)$, which explained $69.7 \%$ of the variation in Rs at a diurnal scale. Soil moisture was correlated significantly with Rs on a daily scale except not during winter, indicating it affected Rs. A model including both soil temperature and soil moisture explained $93.6 \%$ of seasonal variations in Rs. The relationship between Rs and soil temperature during a day showed a clear hysteresis. Rs was significantly and positively $(P<0.01)$ related to gross ecosystem productivity and leaf area index, demonstrating the significance of biotic factors as crucial drivers of Rs. 
1 Title: Soil respiration of a Moso bamboo forest significantly affected by gross ecosystem

2 productivity and leaf area index in an extreme drought event

3 Author names and affiliations :

4 [Author's name] Yuli Liu ${ }^{1,2,3}$, Guomo Zhou*1,2,3, Huaqiang Du*1,2,3, Frank Berninger ${ }^{2,4}$, 5 Fangjie Mao ${ }^{1,2,3}$, Xuejian Li ${ }^{1,2,3}$, Liang Chen ${ }^{1,2,3}$, Lu Cui ${ }^{1,2,3}$, Yangguang Li ${ }^{1,2,3}$, Di'en Zhu ${ }^{1,2,3}$

6 [Affiliation]

$7{ }^{1}$ State Key Laboratory of Subtropical Silviculture, Zhejiang A \& F University, Lin'an 311300, 8 Zhejiang, China

$9 \quad{ }^{2}$ Key Laboratory of Carbon Cycling in Forest Ecosystems and Carbon Sequestration of Zhejiang 10 Province, Zhejiang A \& F University, Lin'an 311300, Zhejiang, China

11 3School of Environmental and Resources Science, Zhejiang A \& F University, Lin'an 311300, 12 Zhejiang, China

$13{ }^{4}$ Department of Forest Ecology, P. O. Box 27, FI-00014, University of Helsinki, Finland

14 * Corresponding author: State Key Laboratory of Subtropical Silviculture, Key Laboratory of 15 Carbon Cycling in Forest Ecosystems and Carbon Sequestration of Zhejiang Province, Zhejiang 16 A \& F University, Lin'an 311300, Zhejiang, China.

17 Email address: zhougm@zafu.edu.cn,dhqrs@126.com 


\section{Abstract}

Moso bamboo has large potential to alleviate global warming through carbon sequestration. Since soil respiration $\left(\mathrm{R}_{\mathrm{s}}\right)$ is a major source of $\mathrm{CO}_{2}$ emissions, we analyzed the dynamics of soil respiration $\left(\mathrm{R}_{\mathrm{s}}\right)$ and its relation to environmental factors in a Moso bamboo (Phllostachys heterocycla $c v$. pubescens) forest to identify the relative importance of biotic and abiotic drivers of respiration. Annual average $\mathrm{R}_{\mathrm{s}}$ was $44.07 \mathrm{t} \mathrm{CO}_{2} \mathrm{ha}^{-1} \mathrm{a}^{-1} \cdot \mathrm{R}_{\mathrm{s}}$ correlated significantly with soil temperature $(P<0.01)$, which explained $69.7 \%$ of the variation in $\mathrm{R}_{\mathrm{s}}$ at a diurnal scale. Soil moisture was correlated significantly with $\mathrm{R}_{\mathrm{s}}$ on a daily scale except not during winter, indicating it affected $\mathrm{R}_{\mathrm{s}}$. A model including both soil temperature and soil moisture explained $93.6 \%$ of seasonal variations in $R_{s}$. The relationship between $R_{s}$ and soil temperature during a day showed a clear hysteresis. $\mathrm{R}_{\mathrm{s}}$ was significantly and positively $(P<0.01)$ related to gross ecosystem productivity and leaf area index, demonstrating the significance of biotic factors as crucial drivers

31 of $\mathrm{R}_{\mathrm{s}}$.

\section{Introduction}

Soils are important sources and sinks in the global carbon budget (Sheng et al., 2010). Soil respiration $\left(\mathrm{R}_{\mathrm{s}}\right)$ is a major source of $\mathrm{CO}_{2}$ emissions from terrestrial ecosystem, and as the second largest carbon flux between the atmosphere and ecosystems it is surpassed only by gross primary production (Raich and Potter ,1995). Soils release approximately 75-100 Pg C per year globally (Bond-Lamberty and Thomson, 2010), nearly 10 times of the amount of $\mathrm{CO}_{2}$ released by the combustion of fossil fuels (Raich and Potter ,1995). Hence, slight shifts in $\mathrm{R}_{\mathrm{s}}$ may cause profound changes in the atmospheric concentration of $\mathrm{CO}_{2}$ and in the accumulation of soil carbon 
40 (Schlesinger and Andrews, 2000), thus subsequently affect global climate.

41 Considering the importance of forest ecosystems in the terrestrial carbon cycle and their response to global climate, $R_{S}$ and its dependence on environmental drivers have been the focus of numerous studies. For instance, soil temperature and moisture of soils are two of the major environmental 
61 covered by Moso bamboo forests increases annually by approximately 3\%, mostly due to

62 afforestation on wastelands (Chen et al., 2009), but also through conversion conifer and broadleaf

63 forests and farmland (Cui et al., 2011; SFAPRC, 2015). Moso bamboo provides many benefits,

64 including high income generation and other ecosystem services, to the forest owners.

65 Notably, the rate of carbon accumulation by Moso bamboo is high. Moso bamboo sequesters 4.91

$66-5.45 \mathrm{t} \mathrm{C} \mathrm{ha}^{-1}$ each year (Zhou and Jiang, 2004), showing great potential for alleviating global

67 warming by carbon fixation. Previous studies on Moso bamboo have concentrated on carbon storage, balance and its distribution in the ecosystem (Li et al., 2013), productivity of bamboo forest (Cheng et al., 2015; Isagi et al., 1997), and the variation in soil organic carbon stocks (Guan et al., 2015). Previous studies reported a close relationship between $\mathrm{R}_{\mathrm{s}}$ and biotic factors in other

forest types (Hibbard et al., 2005), suggesting a coupling between forest canopy assimilation and carbon emissions from soil. However, comparatively little is known about bamboo forests. Thus, given the ecological importance of Moso bamboo forests at regional scale, there is a need for understanding the relationships between biotic and abiotic factors and $\mathrm{R}_{\mathrm{s}}$ in this kind of ecosystem.

In this study, we used soil respiration measurements from a Moso bamboo stand and combined these with measurements of abiotic and biotic factors. Our aims were to explore the temporal dynamics of soil respiration, and to identify the relative importance of the measured environmental factors.

2. Methods

\subsection{Study site}

81 The measurements were done in a Moso bamboo forest with an eddy covariance flux tower in 
82

83

Anji, Zhejiang Province, southeast China $\left(30^{\circ} 28^{\prime} 34.5^{\prime \prime} \mathrm{N}, 119^{\circ} 40^{\prime} 25.7^{\prime \prime} \mathrm{E}\right)$ at $380 \mathrm{~m}$ elevation. The study area has a typical subtropical monsoon climate with distinct seasons (Li et al., 2018; Peel et al., 2007). The average annual air temperature and precipitation in $1981-2010$ was $15.6{ }^{\circ} \mathrm{C}$ and $1413.2 \mathrm{~mm}$, respectively. Monthly average rainfall and air temperature in the study period are shown in Fig.1. The soil type in this area is yellow red soil (Chinese system of soil classification), equivalent to Hapludult in USDA Soil Taxonomy (Soil Survey Staff of USDA, 1999), pH is from 4.4 to 4.8 , and soil bulk density is $1.5 \mathrm{~g} \cdot \mathrm{cm}^{-3}$ (Chen, 2016).

The study area ( $1 \mathrm{~km}$ around the eddy covariance flux tower) was covered by $86.1 \%$ of Moso bamboo forest (Xu et al., 2013). The total area of the forest was 1687 ha. Stand density was 3235 culms per hectare, the average canopy height was $11 \mathrm{~m}$ with a mean diameter at breast height of $9.3 \mathrm{~cm}$. There was only a sparse understory in the study area. The main management activities were harvesting 6 or 7-year old bamboos, and a proportion of new bamboo shoots each year. The forest was not fertilized nor weeded during the study period. Further detailed information of the site is found in Mao et al. (2017). Moso bamboo has a biannual growth pattern. During "off years" (which are the even numbers in our site, i. e. 2012, 2014, 2016) few new bamboo shoots are produced, there is leaf senescence of old leaves, and new leaves grow vigorously (Qiu, 1984). In "on years" which are years with uneven numbers more new bamboo shoots are produced and leaf senescence is limited. In our study site, the study period in 2013 was an "on-year".

\subsection{Experimental design and measurement}

\subsubsection{Soil $\mathrm{CO}_{2}$ flux measurement}

The soil $\mathrm{CO}_{2}$ flux was measured using and automated system consisting of a LI-8100 analyzer and 
103 a LI-8100-104 chamber and a multiplexer (LI-8150) (all LI-COR Inc., Lincoln, NE, USA). Soil

104 respiration measurements were done at two hour intervals between 0:00 and 22:00 on selected

105

106

107

108

109

110

111

112

113

114

115

116

117

118

119

120

121

122

123

sunny days for approximately two weeks (usually from day 10 to day 23 of every month) of every

month in 2013. The duration of each flux measurement was 2 minutes and the fluxes were

calculated by an exponential fit of $\mathrm{CO}_{2}$ against time by Soil Flux Pro, version. One $40 \mathrm{~m} \times 40 \mathrm{~m}$

plot was established around the Flux tower within the forest. Sixteen sampling polyvinyl chloride

(PVC) soil collars $(20 \mathrm{~cm}$ inside diameter, $10 \mathrm{~cm}$ height, and $5 \mathrm{~cm}$ plugged into the soil ) were

randomly placed within the plot. All collars remained permanently in place throughout the study

period. There were few herbs in the Moso bamboo forest. To reduce the disturbance-induced

carbon dioxide emission, the first measurement started at least $24 \mathrm{~h}$ after insertion. The areas inside

collars were kept free of plants by cutting the plants carefully using scissors about monthly during

the year. The data and the performance of the equipment were checked regularly to ensure the

reliability of measurements throughout the year. Soil water content $\left(\mathrm{SWC}, \mathrm{m}^{3} \cdot \mathrm{m}^{-3}\right)$ and soil

temperature $\left(\mathrm{T}_{\mathrm{s}},{ }^{\circ} \mathrm{C}\right)$ were monitored adjacent to each collar at $5 \mathrm{~cm}$ depth with 2 theta probes

inserted vertically (ML2x, Delta-T Inc., UK; Omega Inc., USA) provided with the system. We

defined March to May as spring, June to August as summer, September to November as autumn,

and January, February and December as winter.

\subsubsection{Measurements of environmental variables at the eddy covariance site}

$\mathrm{T}_{\mathrm{s}}$ and SWC were monitored by soil temperature sensors (109SS, Campbell Inc., USA) and soil moisture sensors (CS616, Campbell Inc., USA), respectively, at $5 \mathrm{~cm}, 50 \mathrm{~cm}$ and $100 \mathrm{~cm}$ depths $\left(\mathrm{Ts}_{5}, \mathrm{Ts}_{50}, \mathrm{Ts}_{100}, \mathrm{SWC} 5, \mathrm{SWC} 50, \mathrm{SWC100)}\right.$ close to the eddy covariance tower. Air temperature 
124

125

126

127

128

129

130

131

132

133

134

135

136

137

138

139

140

141

142

143

144

and relative humidity were measured using HMP45C probes (Vaisala, Helsinki, Finland) at $1 \mathrm{~m}$, $7 \mathrm{~m}, 11 \mathrm{~m}, 17 \mathrm{~m}, 23 \mathrm{~m}, 30 \mathrm{~m}$, and $38 \mathrm{~m}$ above the ground. All the data were recorded by a data logger (CR1000, Campbell Inc., USA) and saved as 30-min averages.

\subsubsection{Biological factors measurements}

Gross ecosystem productivity (GEP) was obtained by eddy covariance (EC) technique. An openpath infrared gas analyzer LI-7500 (Li-Cor Inc., Lincoln, NE, USA), in conjunction with a 3dimensional sonic anemometer CSAT3 (Campbell Inc., Logan, UT, USA), was placed at $38 \mathrm{~m}$ above the ground. All the raw flux data were sampled at $10 \mathrm{~Hz}$, and calculated and recorded by a CR1000 data logger (Campbell Inc., USA) as 30-min average values. The flux data was processed using the EdiRe software (University of Edinburgh). A double-coordinate rotation was applied and the Webb-Pearman-Leuning correction was conducted to remove the effects of air-density fluctuations. Daily net ecosystem exchange (NEE) was calculated as the daily sum of the measured $\mathrm{CO}_{2}$ flux and the daily rate of change in $\mathrm{CO}_{2}$ storage below the height of the EC system. Ecosystem respiration (RE) was calculated for each 30-min by extrapolating the exponential regressions between the night NEE at high-friction velocity and soil temperature at the $5 \mathrm{~cm}$ depth and summed into the daily values. Daily gross ecosystem productivity (GEP) was estimated as the difference of daily RE and daily NEE (Song et al., 2017).

The flux data were discarded when the following errors were observed (Yan et al., 2013; Yu et al., 2006; Song et al., 2017) (1) the $\mathrm{CO}_{2}$ flux was beyond the range of -2.0 to $2.0 \mathrm{mg} \mathrm{CO}_{2} \mathrm{~m}^{-2} \mathrm{~s}^{-1}$, $\mathrm{CO}_{2}$ concentration was $<500$ or $>800 \mathrm{mg} \mathrm{m}^{-3}$, and water vapor concentration was outside the range of 0-40 $\mathrm{g} \mathrm{m}^{-3}$; (2) abnormal values, i.e. when the absolute value of the difference between 
145 a numerical value and a continuous five points was $>2.5$ times of its variance; (3) the

146 measurements occurred during precipitation events; (4) the number of valid samples was $<15,000$;

147 (5) low friction velocity was $\operatorname{low}\left(\mathrm{u}^{*}<0.2 \mathrm{~m} \mathrm{~s}^{-1}\right)$. Gaps occurred more frequently at night than 148 during the day. After data filtering, the annual flux data $64 \%$ of the data were retained.

149 Gaps less than $2 \mathrm{~h}$ were linearly interpolated, gaps more than $2 \mathrm{~h}$ were filled with the look-up-table 150 method, which were built up based on the two-adjacent-month periods and two main environmental factors (photosynthetically active radiation and air temperature). For details information, please see the literature by Song et al. (2017).

Leaf area index (LAI) was measured at 6:00-10:00 and 15:00-17:50 of sunny, no cumulus days and with good visibility days. Measurements were done monthly using digital camera provided with a fish-eye lens in combination with MODIS LAI following the methods of Li et al. (2017b).

LAI was reported as the average of three sample points chosen within the $20 \mathrm{~m} \times 20 \mathrm{~m}$ plot on non-rainy days. The LAI data was calculated as mean values $\pm \mathrm{SD}$ (standard deviation).

\subsection{Data analysis}

We analyzed the soil respiration as a function of soil temperature assuming an exponential $\mathrm{Q}_{10}$ 160 type relationship.

$$
R_{s}=a e^{b t}
$$

$$
Q_{10}=e^{10 b}
$$

Where $R_{s}\left(\mu \mathrm{mol} \cdot \mathrm{m}^{-2} \cdot \mathrm{s}^{-1}\right)$ is soil respiration, $T$ is soil temperate at $5 \mathrm{~cm}$ depth, $a$ and $b$ are fit 
167 168

test the statistical significance of differences in soil respiration, environmental (Table 1) and biotic factors (Table 2) between seasons. Regression (including nonlinear and linear regression) and correlation analysis was performed to analyze the relationship between soil respiration, biotic and abiotic variables. All analyses were conducted using the PASW software (PASW Statistics 18.0 for windows, SPSS Inc., Chicago, IL, USA).

\section{Results}

\subsection{Seasonal dynamics of environmental and biotic factors in Moso bamboo forest}

In 2013 , the annual average air temperature was $1.2{ }^{\circ} \mathrm{C}$ higher and total precipitation $114.5 \mathrm{~mm}$ lower than the long-term averages. The $30.7^{\circ} \mathrm{C}$ in July and $30.3^{\circ} \mathrm{C}$ in August (Fig. 1) were as much as 7.9 and $2.8^{\circ} \mathrm{C}$ higher, respectively, than the long-term averages. Precipitation was $57.2 \%$ and $31.5 \%$ of the long-term average in July and August, respectively. The annual rainfall in 2013 was $1298.7 \mathrm{~mm}$, and occurred mostly from May to October. Additionally, it decreased by $57.18 \%$ in July compared with the corresponding period of long term (Fig. 1), showing exceptionally hot and dry conditions. Temperatures at different soil depths $\left(\mathrm{T}_{\mathrm{s} 5}, \mathrm{~T}_{\mathrm{s} 50}\right)$ and air temperature at $1 \mathrm{~m}$ height $\left(T_{a}\right)$ exhibit a similar seasonal pattern (Fig.2A): a gradual increase from January to July, maximum in July, and a slow decrease till December. $\mathrm{T}_{\mathrm{s} 5}$ and $\mathrm{T}_{\mathrm{s} 50}$ changed comparatively more smoothly and steadily than $\mathrm{T}_{\mathrm{a}}$. Soil water content at $5 \mathrm{~cm}$ and $50 \mathrm{~cm}$ depths (SWC5 and SWC50) were obviously affected by rainfall, and were at the lowest in July and August.

Seasonal variation in net ecosystem exchange (NEE), ecosystem respiration (RE) and gross ecosystem productivity (GEP) showed several peaks during 2013. The lowest mean daily NEE was detected in August $\left(0.76 \mathrm{~g} \mathrm{C} \mathrm{m}^{-2}\right)$ (Fig. 2C), and highest in June and September. Additionally, NEE was positive on some rainy and cloudy days. Mean daily NEE, RE and GEP was -2.11 g C 
$189 \mathrm{~m}^{-2}$ day $^{-1}, 5.36 \mathrm{~g} \mathrm{C} \mathrm{m}^{-2}$ day $^{-1}$ and $7.48 \mathrm{~g} \mathrm{C} \mathrm{m}^{-2}$ day $^{-1}$, respectively. Due to the impact of drought,

190 GEP decreased significantly in July and August, being 59.9\% and 80.0\%, respectively, of GEP in

191 the corresponding period in 2011 (Chen et al., 2016). LAI remained at approximately 3.6 in winter

192 and spring, increased gradually starting from March, and reached a maximum (5.92) in July (Fig.

193 2D). Thereafter, LAI decreased slowly, exhibiting the typical growth characteristic of Moso

194 bamboo in an "on year" (Chen, 2016).

195

196

197

198

199

200

201

202

203

204

205

206

207

208

209

\subsection{Diurnal variation of soil $\mathrm{CO}_{2}$ fluxes and its response to temperature}

Soil respiration $\left(R_{s}\right)$ in our forest presented similar diurnal dynamics across all seasons (Fig. 3A).

After a daily minimum occurring between 05:00 to 07:00, it increased slowly reaching the maximum value between 14:00 to 16:00, and then decreased gradually. There were, however, big differences in $R_{s}$ between months. Monthly maximum values of $R_{s}$ ranged from 0.75 in January to $7.52 \mu \mathrm{mol} \mathrm{m} \mathrm{m}^{-2} \mathrm{~s}^{-1}$ in August.

Monthly mean values of $\mathrm{R}_{\mathrm{S}}$ correlated positively with both soil temperature at $5 \mathrm{~cm}$ depth $\left(\mathrm{T}_{\mathrm{S} 5}\right)$ measured by the EC system and air temperature $\left(\mathrm{T}_{\mathrm{a}}\right)(\mathrm{P}<0.01$, not shown), with the correlation with $\mathrm{T}_{\mathrm{s} 5}$ being higher (Fig. 3B, Table 2). An exponential relationship was used to estimate $\mathrm{R}_{\mathrm{s}}$ based on $\mathrm{T}_{\mathrm{s}}$ (Table 1). $\mathrm{T}_{\mathrm{s}}$ explained $69.7 \%$ variation of the variation in $\mathrm{R}_{\mathrm{s}}$ at a diurnal scale, whereas $T_{\mathrm{s} 5}$ explained $63.9 \%$ (not shown). Both exponential regression models were statistically significant $(P$ $<0.01$ ). Plotting the diurnal variation of $\mathrm{R}_{\mathrm{s}}$ against $\mathrm{T}_{\mathrm{s}}$, and $\mathrm{T}_{\mathrm{s} 5}$ (Fig.4) showed a clear hysteresis. Additionally, there was slight discrepancy in the elliptic shape of $T_{\mathrm{s}}$ and $\mathrm{T}_{\mathrm{s} 5}$, and the subtle difference in elliptic shape of both could explain the coefficient or determination $\left(R^{2}\right)$ of exponential regression in the relationship of $\mathrm{T}_{\mathrm{s}}$ and $\mathrm{T}_{\mathrm{s} 5}$ (not shown). 
211 Soil respiration followed a clear seasonal pattern in soil respiration (Fig. 3A), being highest in

212 summer with $5.77 \mu \mathrm{mol} \mathrm{CO} \mathrm{Cm}^{-2} \mathrm{~s}^{-1}$, followed by autumn $\left(3.50 \mu \mathrm{mol} \mathrm{CO} \mathrm{m}^{-2} \mathrm{~s}^{-1}\right)$, and spring $(2.42$

$\left.213 \mu \mathrm{mol} \mathrm{CO} \mathrm{CO}^{-2} \mathrm{~s}^{-1}\right)$, and lowest in winter $\left(0.76 \mu \mathrm{mol} \mathrm{CO}_{2} \mathrm{~m}^{-2} \mathrm{~s}^{-1}\right)$. The average annual soil $\mathrm{CO}_{2}$ flux

214 was $3.11 \mu \mathrm{mol} \mathrm{CO} \mathrm{CO}^{-2} \mathrm{~s}^{-1}$, equating to an annual $\mathrm{R}_{\mathrm{s}}$ of $44.07 \mathrm{t} \mathrm{CO}_{2} \mathrm{ha}^{-1} \mathrm{a}^{-1}$. Temperatures at 215 different heights and depths presented similar seasonal dynamics, being highest in summer and 216 lowest in winter (Fig. 3C). Furthermore, $Q_{10}$ values were small in summer and large in winter 217 (Table 1).

Monthly mean values of LAI, soil temperature and GEP were all significantly related to soil respiration (Table 2 and Fig. 5).

Within each seasonal, there was a complex linear relationship between $\mathrm{SWC}$ and $\mathrm{R}_{\mathrm{s}}$, with significant $(P<0.01)$ negative correlation in summer $\left(R=-0.796, R_{S}=-19.101 * S W C+10.368\right)$, positive linear correlational in autumn $\left(P<0.01, R=0.552, \mathrm{R}_{\mathrm{s}}=47.663 * S W C-7.012\right)$ and spring $\left(P<0.05, R=0.331, \mathrm{R}_{\mathrm{s}}=36.661 * \mathrm{SWC}-6.708\right)$, but no correlation $(P>0.05)$ in winter $(R=0.008)$, indicating that SWC played crucial role in $\mathrm{R}_{\mathrm{s}}$ at the growing period of Moso bamboo. Soil temperature and soil moisture showed significant linear relationship in the summer $(R=-0.939$, $\left.\mathrm{T}_{\mathrm{s}}=-0.013 * S W C+0.559, P<0.001\right)$.

An exponential equation model was used to fit the relationship between different temperatures $\left(T_{s}\right.$, $\left.\mathrm{T}_{\mathrm{s} 5}\right)$ and soil respiration (Fig.3C). The equations of $\mathrm{T}_{\mathrm{s} 5}-\mathrm{Rs}\left(R^{2}=0.954\right)$ and $\mathrm{T}_{\mathrm{s} 50}-\mathrm{R}_{\mathrm{s}}\left(R^{2}=0.929\right)$ both showed higher $R^{2}$ than that of $\mathrm{T}_{\mathrm{s}}-\mathrm{R}_{\mathrm{s}}\left(R^{2}=0.915\right)$, possible because of the relative stability of soil temperature profile measurement in eddy covariance system. Furthermore, due to the complex 
231 relationship between $\mathrm{SWC}$ and $\mathrm{R}_{\mathrm{s}}$, as well as considering combination of temperature and soil

232 moisture, six models were compared that predict $\mathrm{R}_{\mathrm{s}}$ based on soil temperature and soil moistures

233 (Table 3). Based on RMSE and $R^{2}$, the model $\left(R_{s}=\mathrm{a}+\mathrm{b} * \exp \left(\mathrm{c}^{*} \mathrm{~T}_{\mathrm{s}}\right)+\mathrm{d}^{*} \mathrm{~T}_{\mathrm{s}} * \mathrm{SWC}\right)$ showed best

234 result, suggesting $\mathrm{T}_{\mathrm{s}}$ and $\mathrm{SWC}$ could explain $93.6 \%$ temporal variation of $\mathrm{R}_{\mathrm{s}}$ in 2013 . Compared

235 with a soil temperature $\left(\mathrm{T}_{\mathrm{s}}\right)$-soil respiration $\left(\mathrm{R}_{\mathrm{S}}\right)$ equation $\left(\mathrm{Fig} .3 \mathrm{C}, R^{2}=0.915\right)$, It showed a slight

236 increase $R^{2}$ (Table $\left.3, R^{2}=0.936\right)$.

237

238

239

240

241

242

243

244

\section{Discussion}

Our work demonstrates the importance of three factors that affect soil respiration in Moso bamboo: temperature, soil water content and either productivity or LAI. The importance and interactions of the factors will be discussed subsequently.

Of the three factors, soil temperature was the dominant driver of soil respiration with an $R^{2}$ of over 0.8 (Fig. 3C and 5B). Seasonal change of $\mathrm{R}_{\mathrm{s}}$ has been investigated in varying ecosystems. Soil temperature and soil water content are commonly considered to be two major determinants of seasonal variations in measured $\mathrm{R}_{\mathrm{s}}$ (Davidson et al., 1998; Davidson et al., 2006a; Davidson et al., 2012; Sihi et al., 2018). In this study, soil respiration increased with the rising of soil temperature.

Similar results were explored by Shi et al. (2012) on a global scale. However, soil temperature explained only $62.7 \%$ variation of soil respiration during summer (June, July and August). This was not only due to a lower variation of soil temperature during summer months, but also, as shown in Table 1, the temperature sensitivity of soil respiration was markedly lower in the summer, which was likely caused by low SWC values. Additionally, plots of soil respiration against daily temperature patterns show a rather flat relationship for the summer with a strong hysteresis. Similar 
252 findings have been reported in Moso bamboo forest of subtropical China by Tang et al. (2016) and

253 Song et al. (2013). Depth of the soil temperature measurement affected the explanatory power of

254 soil temperature. The explanatory power of the temperature in the organic layer was highest and 255 decreased with the depth of the measurements. This indicates that most of the respiration originates 256 from the organic layer (Davidson et al., 2006b). Zhang et al. (2016) made similar observations in 257 winter wheat ecosystems. While Dai et al. (2004) found soil respiration of wheat was highly correlated with soil temperature at $10 \mathrm{~cm}$ depth.

The relationship between soil carbon efflux and soil temperature showed a diurnal hysteresis (Fig.

4). This indicates that there is a delayed effect of the rapidly varying temperature and diurnal variation of soil respiration, similar to the studies by Högberg et al. (2008), Abramoff et al. (2017) and Savage et al. (2009). One explanation is different diurnal temperature pattern at different depths and delays due to the transport of $\mathrm{CO}_{2}$ from the sites of respiration to the soil surface (Graf et al., 2008). Furthermore, other research suggested that the length of the delay could vary among different species (Raich and Schlesinger, 1992). The hysteresis could also be an artifact for measuring soil temperature at a different depth than respiration is occurring. However, we tried different depths to measure soil temperature. Since the depth of the measurements of soil temperature varies between studies, it might be difficult to compare the sensitivity of soil respiration to soil temperature between studies (Zhang et al., 2016). Previous research suggested diurnal variation of $R_{s}$ was out of phase with corresponding $T_{s}$ at $2 \mathrm{~cm}$ depth, resulting in significant hysteresis (Gaumont-Guay et al., 2006). As discussed above, there may be two possible reasons (1) effects of diurnal variations of root respiration supplied by newly produced 
273 photosynthetic products and (2) diurnal variations of soil water content near the critical value

274 (Bahn et al., 2008; Davidson et al., 2012; Wang et al., 2015; Sihi et al., 2018), while further reasons

275 for this (especially in winter) are needed controlled experiments to explore and demonstrate.

276 The relationship between soil respiration and soil moisture was more complicated in our study.

277 Soil moisture improved marginally our models of soil respiration with a better fit of the models

278 particularly in the dry summer 2013. No significant correlation was found between soil respiration and soil moisture in 2013 (Fig. 3D). Similar findings had been reported for Moso bamboo forest in Zhejiang province (Song et al., 2013). However, soil moisture had a negative statistically significant $\left(P<0.001, R=-0.796, R_{S}=-19.101 * S W C+10.368\right)$ correlation with soil respiration in summer while correlation in the other seasons was positive. Previous observation indicated a pronounced correlation between $\mathrm{R}_{\mathrm{s}}$ and $\mathrm{SWC}$ in subtropical forests (Sheng et al., 2010; Liu et al., 2011). The negative correlation of soil respiration and soil moisture in our study was probably caused by a spurious correlation of soil temperature and soil moisture during summer $(R=-0.939$, $\left.\mathrm{T}_{\mathrm{s}}=-0.013 * S W C+0.559, P<0.001\right)$. The cause of a nonexistent or negative linear correlation between SWC and Rs could be that natural variation of SWC covers only a part of response curve (at low to medium SWC, $\mathrm{R}_{\mathrm{s}}$ depends positively on it because water is limiting, then there might be a plateau and at high SWC oxygen transport to the soil depth and transport of $\mathrm{CO}_{2}$ back might be blocked) ( Linn and Doran, 1984; Xu et al., 2004). When we fitted non-linear models to soil respiration using temperature and soil moisture we got only a small increase in the $R^{2}$ when soil moisture was included into the model. We have also checked the interaction between SWC and temperature (shown in Table 3) and our best model (last row in Table 3) shows that a model which 
294 includes interactions was the best. This indicates that soil moisture was, even in the dry year of

295 2013, not an important limitation of soil respiration.

296 The models of soil respiration suggest that the temperature sensitivity of soil respiration declines

297 when soil moisture is decreasing (Almagro et al., 2009; Jassal et al., 2008; Wang et al., 2006), this

298 may be due to the diurnal variation of soil moisture near the criticality value. Also, $Q_{10}$ varied over

299 the different seasons (Table 1). Due to smaller amplitude of soil temperature in deeper layers

300 (Pavelka et al., 2007), $Q_{10}$ values estimated from deeper soil layers tended to be larger than those

of shallower layers. This can partly explain the discrepancy between $\mathrm{T}_{\mathrm{a}}, \mathrm{T}_{\mathrm{s}}$, and $\mathrm{T}_{\mathrm{s} 5} \cdot Q_{10}$ was about

2.80 in our study, within range of 1.33 5.53 estimated for forests in China (Chen et al., 2008),

lower than 4.09 in Moso bamboo forest of central Taiwan (Hsieh et al., 2016), but higher than

median of 2.0 2.4 (Hashimoto, 2005).

Previous observation pointed out that annual $Q_{10}$ value was not only an indicator of the response

to soil temperature, but also a comprehensive response to variations of other factors (i.e. SWC,

root biomass, root growth, amplitude of $\mathrm{R}_{\mathrm{s}}$, and other seasonal processes, Yuste et al., 2004).

Another driver of soil respiration is the phenology of Moso bamboo which shows a large variation

in below ground activities. In the spring, carbon is allocated to the production of new bamboo

shoots. After bamboo has completed its main growth period in summer and new leaves are fully-

expanded, it accumulates nutrient substance and allocates its main growth to the rhizome. Then in

autumn Moso bamboo starts to hatch bamboo shoots for the next year (Chen et al., 2016). In this

growing phase, soil moisture was a key factor for soil respiration. Subsequently, the stand got into

314 overwintering stage. Soil moisture became less important in this period. Consequently, the 
importance of soil moisture for soil respiration varies among seasons and was more important

during the time of active growth of Moso bamboo. However, soil temperature rather than soil

moisture remained the most important drivers of soil respiration (Janssens and Pilegaard, 2003).

The explanation for the differences in soil respiration and $Q_{10}$ values are driven by the seasonal

pattern of gross primary production which drives substrate supply to the root and rhizosphere

(Bahn et al., 2008). Currently several authors have reported productivity should be considered to

improve the prediction of soil respiration (Bahn et al., 2008; Hibbard et al., 2005; Vargas et al.,

2011; Zhang et al., 2016). Numerous studies have shown close relations between soil respiration

and canopy photosynthesis at different timescales. Högberg et al. (2008) reported that soil

respiration was largely driven by recent primary production of the vegetation. Monthly soil

respiration was significantly related to LAI and GEP in our study (Fig. 5A, 5C and 5D). The

finding agreed with the view of a coupling of photosynthesis and soil respiration. Likewise, Yuste

et al. (2004) found that seasonal $R_{s}$ was positively related to LAI. Bahn et al (2008) suggested $R_{s}$

was closely related to LAI across grassland sites. In our study, LAI was closely related to the

productivity of vegetation. There was similar monthly variation pattern of LAI and $\mathrm{T}_{\mathrm{a}}$ in our study,

which in turn increased the difficulty to detect relationships of $\mathrm{R}_{\mathrm{s}}$ in relation to biological variable.

Soil respiration is a complex biological process, composed of several processes from both

autotrophic and heterotrophic organisms. Besides soil temperature and soil water content, it is

known that soil respiration is partly explained by forest type, stand age and altitude in subtropical

forests (Wang et al., 2011). Additionally, other variables such as management (i.e. fertilization, 
336

337

338

339

340

341

342

343

344

345

346

and Doran, 1984) and physical properties, root biomass and extreme weather (e.g. warming, precipitation events, short-term drought events), all have indirect and direct effects on soil respiration. However, how these influence autotrophic and heterotrophic processes is not well understood and should be a subject of further research.

\section{Conclusions}

Soil respiration $\left(\mathrm{R}_{\mathrm{s}}\right)$ in the Moso bamboo forest exhibited both daily and seasonal dynamic patterns, with its highest values in summer and lowest values in winter. Soil respiration correlated positively with soil temperature $(P<0.01)$, which explained $69.7 \%$ of variation in $\mathrm{R}_{\mathrm{s}}$ at a diurnal scale and $91.5 \%$ of variation in $\mathrm{Rs}$ for the whole year. $\mathrm{R}_{\mathrm{s}}$ correlated positively with soil moisture in spring, autumn, and negatively in summer, implying that moisture played a crucial role in different growth phases, but did not correlate significantly on daily scale, this may result from soil carbon substrate supply limiting soil microbial respiration in summer, and enhancing soil respiration in winter given substrate diffusion to the reaction site, which is generally driven by the thickness of the soil water film. The model that included soil temperature and soil moisture explained $93.6 \%$ of the seasonal variation in $R_{s}$. The relationship between $R_{s}$ and different soil temperature exhibited a clear hysteresis. Soil respiration correlated positively $(P<0.01)$ with gross ecosystem productivity and LAI in our study, showing the significance of biotic factors in affecting soil respiration, and a need for future research to analyze the relationship between canopy photosynthesis and soil $\mathrm{CO}_{2}$ flux.

\section{Acknowledgements}

We thank Li Y for giving comments that greatly improved this manuscript. Tan Y provided field 
357

358

359

360

361

362

363

364

365

366

367

368

369

370

371

372

373

374

375

376

377

378

379

380

381

382

383

384

385

386

387

388

389

390

391

392

393

assistance. And we also would like to thank Professor Jiang Hong 's team for their invaluable

support with the flux data collection. The authors also would like to thank the editor, three

reviewers and Prof. Petri Penttinen for their contribution to the peer reviews of this study.

\section{References}

Almagro, M., Lopez, J., Querejeta, J.I. and Martinezmena, M., 2009. Temperature dependence of soil $\mathrm{CO}_{2}$ efflux is strongly modulated by seasonal patterns of moisture availability in a Mediterranean ecosystem. Soil Biology \& Biochemistry, 41(3): 594-605.

Abramoff, R.Z., Davidson, E.A., and Finzi, A.C., 2017. A parsimonious modular approach to building a mechanistic belowground carbon and nitrogen model. J. Geophys. Res.:Biogeosci. 122 (9), JG003796.

Bahn M, Rodeghiero M, Andersondunn M, Dore S, Gimeno C, Drösler M, Williams M, Ammann C, Berninger F, Flechard C, Jones S, Balzarolo M, Kumar S, Newesely C, Priwitzer T, Raschi A, Siegwolf R, Susiluoto S, Tenhunen J, Wohlfahrt G, and Cernusca A. 2008. Soil respiration in European grasslands in relation to climate and assimilate supply. Ecosystems 11: 1352-1367.

Bond-Lamberty, B. and Thomson, A., 2010. A global database of soil respiration data. Biogeosciences Discussions, 7(6): 1915-1926.

Chen GS, Yang YS, Lv PP, Zhang YP, and Qian XL. 2008. Regional patterns of soil respiration in China's forests. Acta Ecol. Sin. 28(4): 1748-1759 (in Chinese with English Abstract).

Chen X, Zhang X, Zhang Y, Trevor B, and He X. 2009. Changes of carbon stocks in bamboo stands in China during 100 years. For. Ecol. Manage. 258, 1489-1496.

Chen XF. 2016. Carbon fluxes and their response mechanisms in a Phyllostachys edulis ecosystem In Anji county, Zhejiang A \& F University.

Cheng XF, Shi PJ, Hui C, Wang FS, Liu GH, and Li BL. 2015. An optimal proportion of mixing broad-leaved forest for enhancing the effective productivity of Moso bamboo. Ecol. Evol. 5(8): 1576-1584.

Cui RR, Du HQ, Zhou GM, Xu XJ, Dong DJ, and Lv YL. 2011. Remote sensing-based dynamic monitoring of moso bamboo forest and its carbon stock change in Anji County. J. Zhejiang A \& F Univ. 28, 422-431.

Davidson EA, Belk E, and Boone RD. 1998. Soil water content and temperature as independent or confounded factors controlling soil respiration in a temperate mixed hardwood forest. Glob. Change Biol. 4(2): 217-227.

Davidson EA, Janssens IA and Luo Y. 2006a. On the variability of respiration in terrestrial ecosystems: moving beyond $\mathrm{Q}_{10}$. Glob. Change Biol., 12(2): 154-164.

Davidson EA, Savage KE, Trumbore SE, and Borken W. 2006b. Vertical partitioning of $\mathrm{CO}_{2}$ production within a temperate forest soil. Glob. Change Biol. 12(6): 944-956.

Davidson EA, Samanta S, Caramori SS, and Savage K. 2012. The dual Arrhenius and Michaelis- 
Menten kinetics model for decomposition of soil organic matter at hourly to seasonal time scales. Glob. Change Biol. 18(1): 371-384.

FAO, 2010. Global Forest Resources Assessment 2010: Main Report, Rome.

Gao Q, Hasselquist NJ, Palmroth S, Zheng Z, and You W. 2014. Short-term response of soil respiration to nitrogen fertilization in a subtropical evergreen forest. Soil Biol. Biochem. 76(1): 297-300.

Graf A, Weihermüller L, Huisman JA, Herbst M, Bauer J, and Vereecken H. 2008. Measurement depth effects on the apparent temperature sensitivity of soil respiration in field studies. Biogeosci. 5: 1175-1188.

Gao H G, and Liu W. 2011. Characteristics of soil respiration in fallow and its influencing factors at arid- highland of Loess Plateau. Acta Ecol. Sin. 5217-5224.

Gaumont-Guay D, Black TA, Griffis TJ, Barr AG, Jassal RS, and Nesic Z. 2006. Interpreting the dependence of soil respiration on soil temperature and water content in a boreal aspen stand. Agric. For. Meteorol. 140(1-4): 220-235.

Guan F, Tang X, Fan S, Zhao J, and Peng C. 2015. Changes in soil carbon and nitrogen stocks followed the conversion from secondary forest to Chinese fir and Moso bamboo plantations. Catena 133: 455-460.

Guan F, Xia M, Tang X, and Fan S. 2017. Spatial variability of soil nitrogen, phosphorus and potassium contents in Moso bamboo forests in Yong'an City, China. Catena 150: 161-172.

Högberg P, Högberg MN, Göttlicher SG, Betson NR, Keel SG, Metcalfe DB, Campbell C, Schindlbacher A, Hurry V, Lundmark T, and Linder S. 2008. High temporal resolution tracing of photosynthate carbon from the tree canopy to forest soil microorganisms. New Phytol. 177(1): 220-228.

Han G X, Zhou G S, and Xu Z Z. 2008. Temporal variation of soil respiration and its affecting factors in a maize field during maize growth season. Chinese J. Plant Ecol. 32(3):719-733.

Hashimoto S. 2005. Temperature sensitivity of soil $\mathrm{CO}_{2}$ production in a tropical hill evergreen forest in northern Thailand. J. For. Res. 10(6): 497-503.

Hibbard KA, Law BE, Reichstein M, and Sulzman J. 2005. An analysis of soil respiration across northern hemisphere temperate ecosystems. Biogeochemistry 73(1): 29-70.

Hsieh IF, Kume T, Lin MY, Cheng CH, and Miki T. 2016. Characteristics of soil $\mathrm{CO}_{2}$ efflux under an invasive species, Moso bamboo, in forests of central Taiwan. Trees 30(5): 1749-1759.

Isagi Y, Kawahara T, Kamo, K, and Ito H. 1997. Net production and carbon cycling in a bamboo Phyllostachys pubesces stand. Plant Ecol. 130(1): 41-52.

Jassal RS, Black TA, Novak MD, Gaumont-Guay D, and Nesic Z. 2008. Effect of soil water stress on soil respiration and its temperature sensitivity in an 18-year-old temperate Douglas-fir stand. Glob. Change Biol. 14(6): 1305-1318.

Janssens IA, and Pilegaard K. 2003. Large seasonal changes in $\mathrm{Q}_{10}$ of soil respiration in a beech forest. Glob. Change Biol. 9(6): 911-918.

Köster, K., Berninger, F., Lindén, A., Köster, E. and Pumpanen, J. 2014. Recovery in fungal biomass is related to decrease in soil organic matter turnover time in a boreal fire chronosequence. Geoderma. 235-236: 74-82. 
Li G, Kim S, Han S, Chang H, and Son Y. 2017a. Effect of soil moisture on the response of soil respiration to open-field experimental warming and precipitation manipulation. Forests $\mathbf{8}$ : 56, doi:10.3390/f8030056

Li L H, Wang Q., Bai Y F, Zhou G S, and Xing X R, 2000. Soil respiration of a Leymus chinensis grassland stand in the Xilin River Basin as affected by over-grazing and climate. Acta Phytoecol. Sin. 27(5): 644-649.

Li X, Mao F, Du H, Zhou G, Xu X, Han N, Sun S, Gao G, and Chen L. 2017b. Assimilating leaf area index of three typical types of subtropical forest in China from MODIS time series data based on the integrated ensemble Kalman filter and PROSAIL model. Isprs J. Photogram. Rem. Sens. 126: 68-78.

Li X, Du H, Mao F, Zhou G, Chen L, Xing L, Fan W, Xu X, Liu Y, Cui L, Li Y, Zhu D, and Liu T. 2018. Estimating bamboo forest aboveground biomass using EnKF-assimilated MODIS LAI spatiotemporal data and machine learning algorithms. Agric. Forest Meteorol. 256257: 445-457.

Li YF, Zhang JJ, Chang SX, Jiang PK, Zhou GM, Fu SL, Yan ER, Wu JS, and Lin L. 2013. Longterm intensive management effects on soil organic carbon pools and chemical composition in Moso bamboo (Phyllostachys pubescens) forests in subtropical China. For. Ecol. Manage. 303(5): 121-130.

Linn DM and Doran JW. 1984. Effect of water-filled pore space on carbon dioxide and nitrous oxide production in tilled and nontilled soils. J. Soil Sci. Soc. of Am. (USA), 89(3): 647653.

Liu J, Jiang P, Wang H, Zhou G, Wu J, Yang F, and Qian X. 2011. Seasonal soil $\mathrm{CO}_{2}$ efflux dynamics after land use change from a natural forest to Moso bamboo plantations in subtropical China. For. Ecol. Manage. 262(6): 1131-1137.

Liu Y, Liu S, Wan S, Wang J, Luan J, and Wang H. 2016. Differential responses of soil respiration to soil warming and experimental throughfall reduction in a transitional oak forest in central China. Agric. For. Meteorol. 226-227: 186-198.

Lloyd J, and Taylor JA. 1994. On the temperature dependence of soil respiration. Funct. Ecol. 8(3): 315-323.

Lu X, Jiang H, Liu J, Sun C, Wang Y, and Jin J, 2014. Comparing Simulated Carbon Budget of a Lei Bamboo Forest with Flux Tower Data. Terr. Atmos. Ocean. Sci. 25, 359-368.

Luo D, Cheng R, Shi Z, Wang W, Xu G, and Liu S. 2016. Impacts of nitrogen-fixing and nonnitrogen-fixing tree species on soil respiration and microbial community composition during forest management in subtropical China. Ecol. Res. 5: 1-11.

Mahecha MD, Reichstein M, Carvalhais N, Lasslop G, Lange H, Seneviratne SI, Vargas R, Ammann C, Arain MA, Cescatti A, Janssens IA, Migliavacca M, Montagnani L, and Richardson AD. 2010. Global convergence in the temperature sensitivity of respiration at ecosystem level. Science 329: 838-840.

Mao F, Zhou G, Li P, Du H, Xu X, Shi Y, Mo L, Zhou Y, and Tu G. 2017. Optimizing selective cutting strategies for maximum carbon stocks and yield of Moso bamboo forest using BIOME-BGC model. J. Environ. Manage. 191: 126-135. 
Muñoz-Rojas M, Lewandrowski W, Erickson TE, Dixon KW, and Merritt DJ. 2016. Soil respiration dynamics in fire affected semi-arid ecosystems: Effects of vegetation type and environmental factors. Sci. Total Environ. 572: 1385-1394.

Oishi AC, Palmroth S, Butnor JR, Johnsen KH, and Oren R. 2013. Spatial and temporal variability of soil $\mathrm{CO} 2$ efflux in three proximate temperate forest ecosystems. Agric. For. Meteorol. 171-172(3): 256-269

Pavelka M, Acosta M, Marek MV, and Kutsch W. 2007. Dependence of the Q 10 values on the depth of the soil temperature measuring point. Plant Soil 292(1): 171-179.

Peel MC, Finlayson BL, Mcmahon TA. 2007. Updated world map of the Köppen-Geiger climate classification. Hydrol. Earth Syst. Sci. 11, 259-263.

Qiu F.1984. The on-year and off-year of phyllostarchys pubescens forests and their control. J. Bamboo Res. 32(2): 62-69.

Raich JW, and Potter CS. 1995. Global patterns of carbon dioxide emissions from soils. Global Biogeochem. Cycles 9(1): 23-36.

Raich JW, and Schlesinger WH. 1992. The global carbon dioxide flux in soil respiration and its relationship to vegetation and climate. Tellus (B chem. Phys. Meteorol.) 44(2): 81-99.

Savage, K., Davidson, E.A., Richardson, A.D., Hollinger, D.Y., 2009. Three scales of temporal resolution from automated soil respiration measurements. Agric. Forest Meteorol. 149 (11), 2012-2021.

Schlesinger WH, and Andrews JA. 2000. Soil respiration and the global carbon cycle. Biogeochemistry 48(1): 7-20.

SFAPRC. 2015. Forest Resources in China - The 8th National Forest Inventory. State Forestry Administration, P.R. China, Beijing, China.

Sheng H, Yang YS, Yang ZJ, Chen GS, Xie JS, Guo JF, and Zou SQ. 2010. The dynamic response of soil respiration to land-use changes in subtropical China. Global Change Biol. 16(3): 1107-1121.

Shi Z, Wang F, and Liu Y. 2012. Response of soil respiration under different mycorrhizal strategies to precipitation and temperature. J. Soil Sci. Plant Nutr. 12(3): 411-420.

Sihi D, Davidson EA, Chen M, Savage KE, Richardson AD, Keenan TF, and Hollinger DY. 2018. Merging a mechanistic enzymatic model of soil heterotrophic respiration into an ecosystem model in two AmeriFlux sites of northeastern USA. Agric. For. Meteorol. 252: 155-166.

Song X, Yuan H, Kimberley MO, Jiang H, Zhou G, and Wang H. 2013. Soil $\mathrm{CO}_{2}$ flux dynamics in the two main plantation forest types in subtropical China. Sci. Total Environ. 444(2): 363-368.

Song X, Chen X, Zhou G, Jiang H, and Peng C. 2017. Observed high and persistent carbon uptake by Moso bamboo forests and its response to environmental drivers. Agric. For. Meteorol. 247: 467-475.

Soil Survey Staff of United States, Department of Agriculture (USDA). 1999. Soil taxonomy: a basic system of soil classification for making and interpreting soil survey. Agriculture Handbook, No. 436., Washington, DC, USA.

Tang J, and Baldocchi D D. 2005. Spatial-temporal variation in soil respiration in an oak-grass 
savanna ecosystem in California and its partitioning into autotrophic and heterotrophic components. Biogeochemistry 183-207.

van't Hoff, J.H., 1884. Etudes de dynamique chimique (Studies of Chemical dynamics), Frederik Muller and Co., Amsterdam, the Netherlands.

Vargas R, Baldocchi DD, Bahn M, Hanson PJ, Hosman KP, Kulmala L, Pumpanen J, and Yang B. 2011. On the multi-temporal correlation between photosynthesis and soil $\mathrm{CO}_{2}$ efflux: reconciling lags and observations. New Phytol. 191: 1006-1017.

Wang B, Jiang Y, Wei X, Zhao G, Guo H, and Bai X. 2011. Effects of forest type, stand age, and altitude on soil respiration in subtropical forests of China. Scand. J. For. Res. 26(1): 40-47.

Wang C, Yang J, and Zhang, Q., 2006. Soil respiration in six temperate forests in China. Glob. Change Biol. 12(11): 2103-2114.

Wang F, Zhou G, Jia B, and Wang Y. 2003. Effects of heat and water factors on soil respiration of restoring Leymus chinensis steppe in degraded land. Acta Phytoecol. Sin. 27: 644-649.

Wang G, Jagadamma S, Mayes M. A., Schadt, C. W., Steinweg, J. M., Gu, L. and Post, W. M., 2015. Microbial dormancy improves development and experimental validation of ecosystem model. The ISME journal. 9: 226, doi:10.1038/ismej.2014.120 (2015).

Willaarts BA, Oyonarte C, Muñoz-Rojas M, Ibáñez JJ, Aguilera PA. 2016. Environmental factors controlling soil organic carbon stocks in two contrasting Mediterranean Climatic Areas of Southern Spain. Land Degrad. Develop. 27(3): 603-611.

Wu J, Zhang Q, Yang F, Lei Y, Zhang Q, and Cheng X. 2017. Does short-term litter input manipulation affect soil respiration and its carbon-isotopic signature in a coniferous forest ecosystem of central China? Appl. Soil Ecol. 113: 45-53.

Xu X, Zhou G, Liu S, Du H, Mo L, Shi Y, Jiang H, Zhou Y, and Liu E. 2013. Implications of ice storm damages on the water and carbon cycle of bamboo forests in southeastern China. Agric. For. Meteorol. 177: 35-45.

Xu L, Baldocchi DD, and Tang J, 2004. How soil moisture, rain pulses, and growth alter the response of ecosystem respiration to temperature. Glob. Biogeochem. Cycles. 18, GB4002, doi:10.1029/2004GB 002281.

Yan J, Zhang Y, Yu G, Zhou G, Zhang L, Li K, Tan Z, and Sha L. 2013. Seasonal and inter-annual variations in net ecosystem exchange of two old-growth forests in southern China. Agric. For. Meteorol. 182-183: 257-265.

Yu G, Fu Y, Sun X, Wen X, and Zhang L.. 2006. Recent progress and future directions of ChinaFLUX. Sci. China D: Earth Sci. 49: 1-23.

Yuste JC, Janssens IA, and Carrara AR. 2004. Annual $\mathrm{Q}_{10}$ of soil respiration reflects plant phenological patterns as well as temperature sensitivity. Global Change Biol. 10(2): 161169.

Zhang X, Shen B, Quan Q, Dong L, and Tian K. 2016. Soil respiration rates and its affecting factors in winter wheat land in the Weihe Plain, Northwest China. Chin. J. Appl. Ecol. 27(8): 2551-2560.

Zhou G, and Jiang P. 2004. Density, storage and spatial distribution of carbon in Phyllostachy pubescens forest. Sci. Sil. Sin. 40(6): 20-24. 
558 Zhou G S, Jia B R, Han G X, and Zhou L. 2008. Assumption of universal assessment model for 559 soil respiration. Sci. in China (C): life Sci. 38(3), 293-302.

560 


\section{Figure 1 (on next page)}

Monthly and long-term average air temperature $\left(\mathrm{T}_{\mathrm{a}}\right)$ and precipitation at the study site

White circles are monthly air temperature in 2013, black triangles denote long-term average air temperature; grey rectangles are monthly precipitation in 2013, white ones denote longterm average precipitation. 
Peers

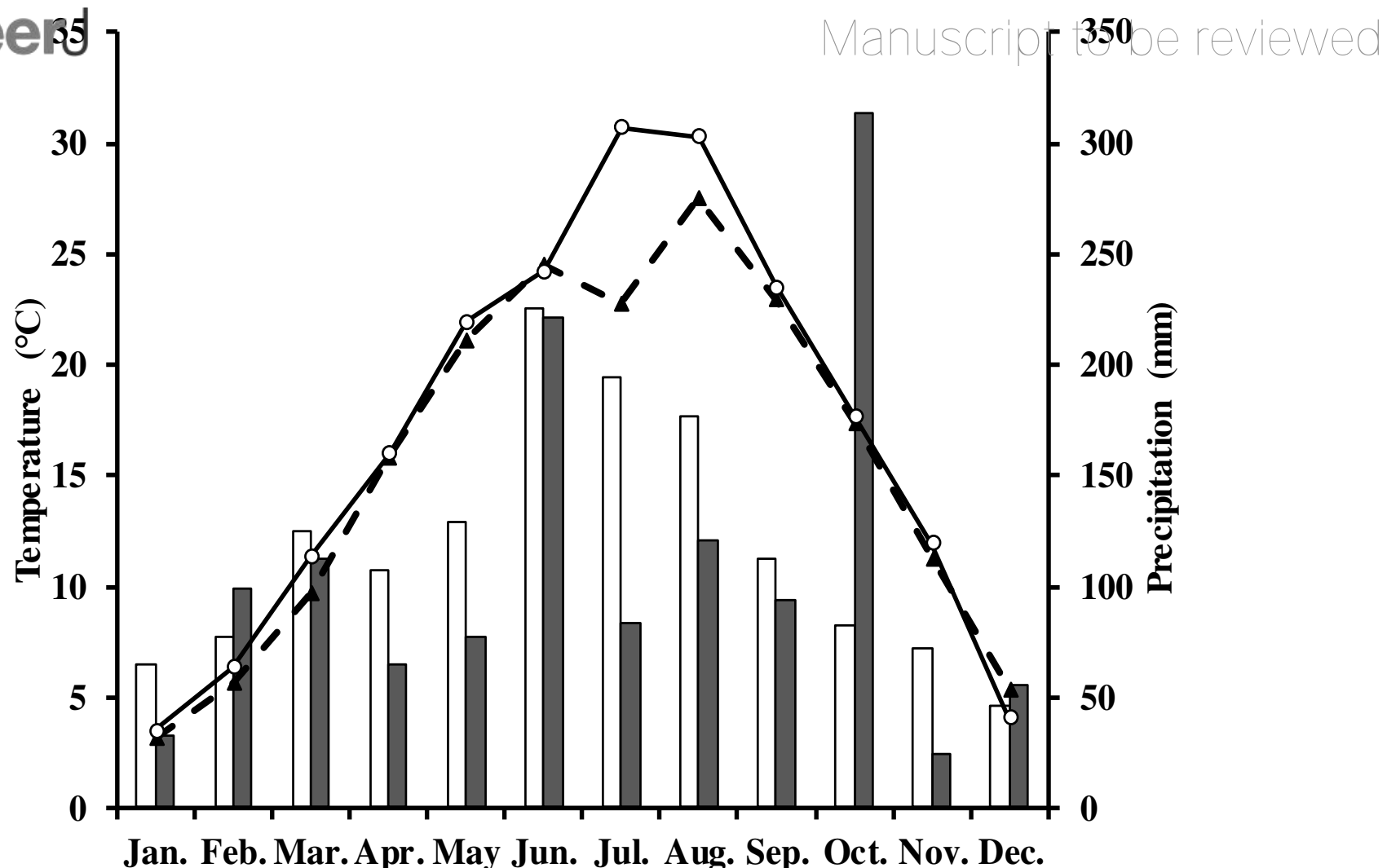


Figure 2 (on next page)

Seasonal variation of abiotic and biotic factors of Moso bamboo forest in 2013.

(A) daily temperature $\left({ }^{\circ} \mathrm{C}\right)$ of air $(\mathrm{Ta})$ and soil at $5 \mathrm{~cm}\left(\mathrm{~T}_{\mathrm{s5}}, 50 \mathrm{~cm}\left(\mathrm{~T}_{\mathrm{s50}}\right)\right.$ depth, (B) Daily rainfall amount $(\mathrm{mm})$ and soil water content $\left(\mathrm{m}^{3} \mathrm{~m}^{-3}\right)$ at $5 \mathrm{~cm}$ depth $\left(\mathrm{SWC}_{5}\right)$ and $50 \mathrm{~cm}$ depth $\left(\mathrm{SWC}_{50}\right)$, (C) daily carbon fluxes (NEE, RE, GEP, $\left.\mathrm{gC} \mathrm{m}^{-2}\right)$, (D) mean monthly LAl $\left(\mathrm{m}^{2} \mathrm{~m}^{-2}\right)$ during the study period Mean \pm SD $(n=3)$. 

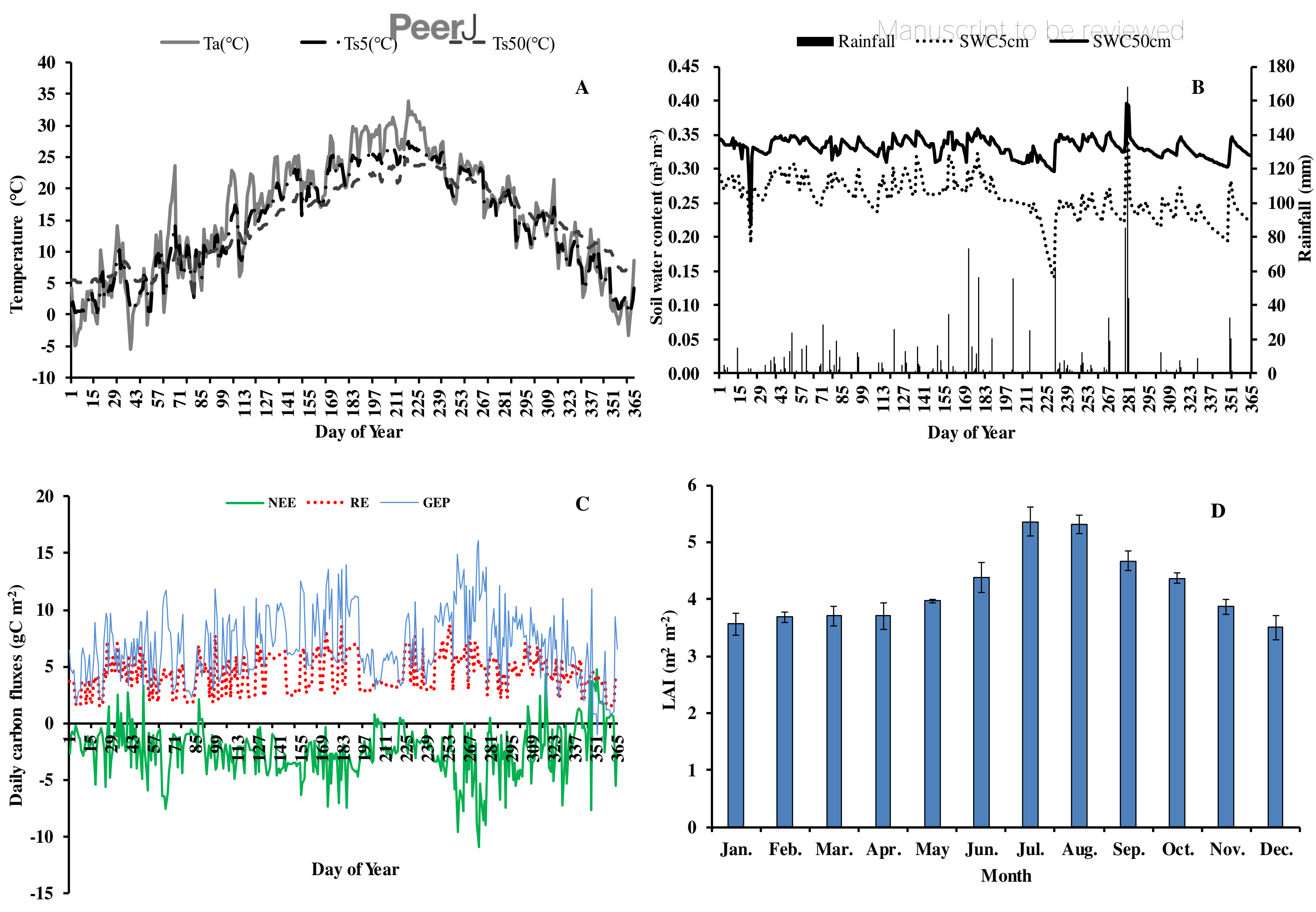


\section{Figure 3 (on next page)}

Diurnal, seasonal dynamic of soil respiration and the relationship between related factors and soil respiration in Moso bamboo forest.

(A, error bars denote standard error of means, $n=12$ ). Seasonal variation of soil respiration

$\left(B, T_{5}\right.$, black circle, $T_{55}$, white diamond, $\left.n=144\right)$, and $(C)$ seasonal variation of different

temperatures; (D) relationship between soil water content and soil respiration $(n=144)$ error bars indicate standard deviation of the means $(n=12)$. 

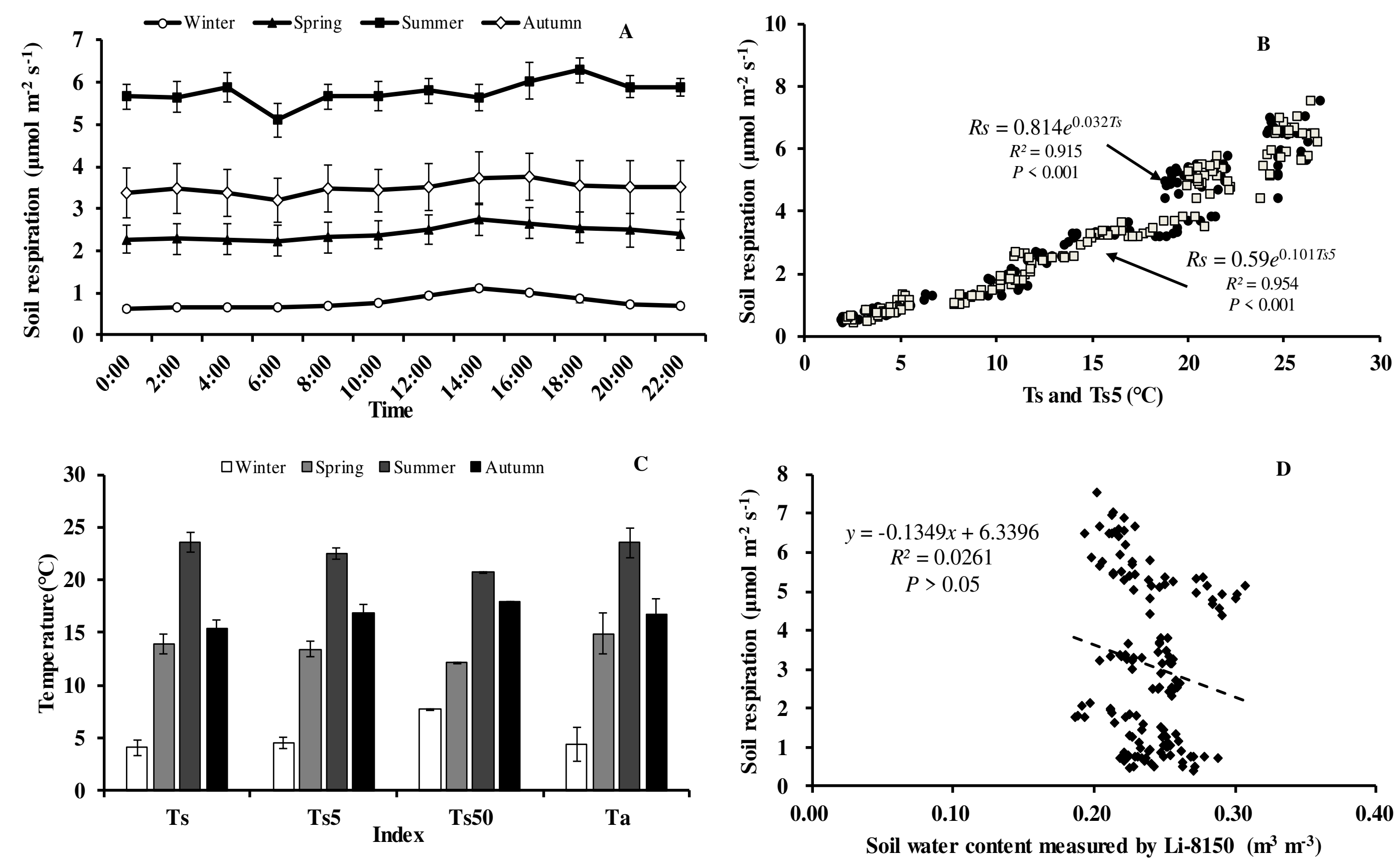
Figure 4(on next page)

Mean diurnal changes of $R_{s}$ in response to $T_{s}$ and $T_{s 5}$ in different months of Moso bamboo forest.

$R_{s}$ denotes soil respiration, $T_{s}$ denotes soil temperature measured by Li-8150, $T_{s 5}$ denotes soil temperature at $5 \mathrm{~cm}$ depth measured by eddy covariance technique. one month of the season was chosen. 
Jan.
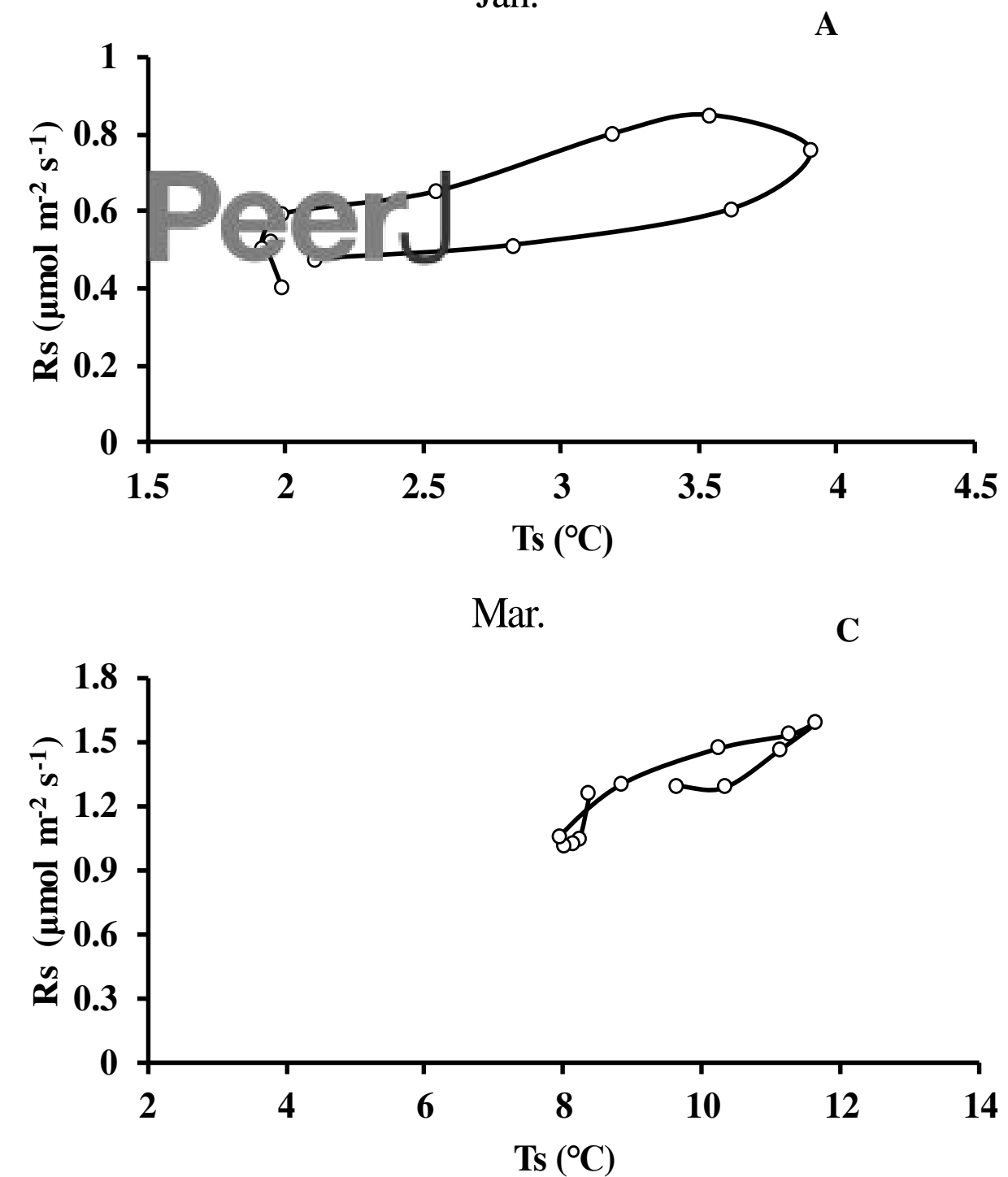

Jun.

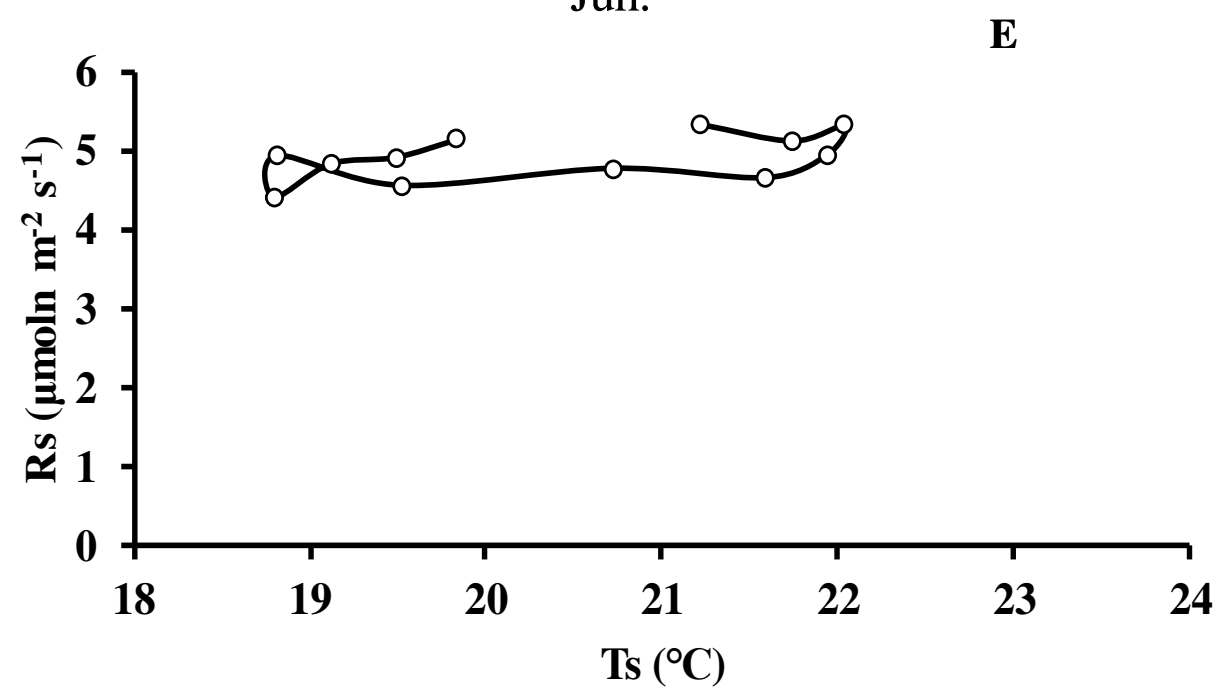

Sep.

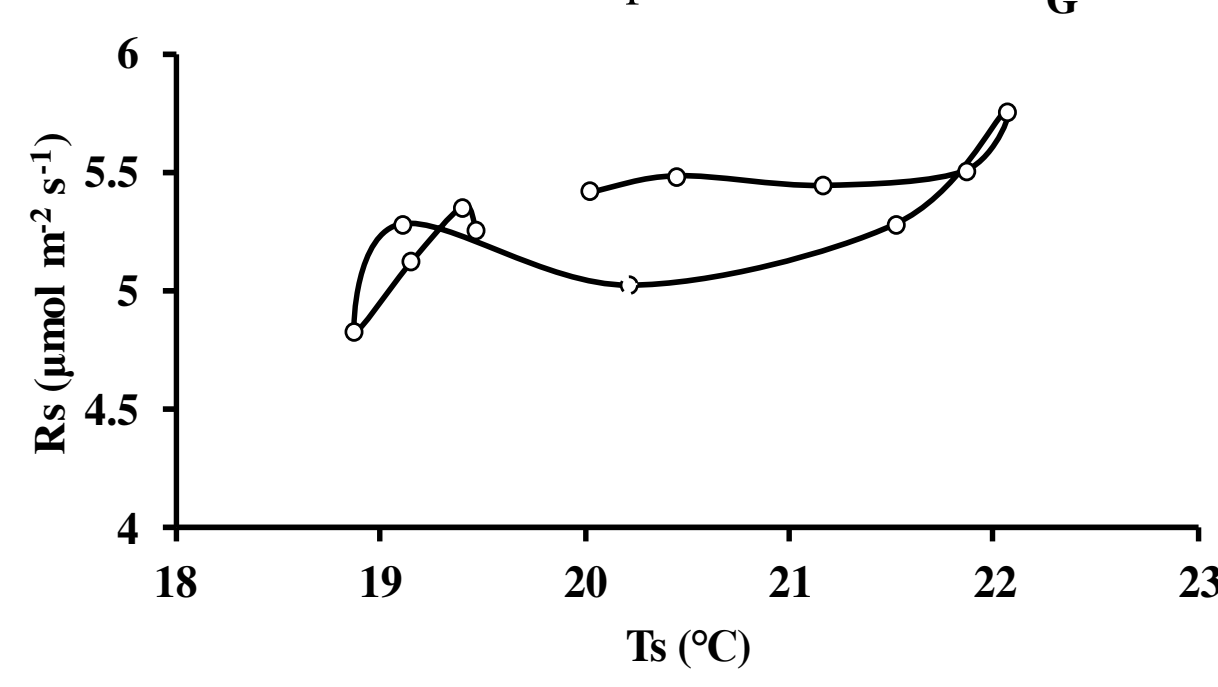

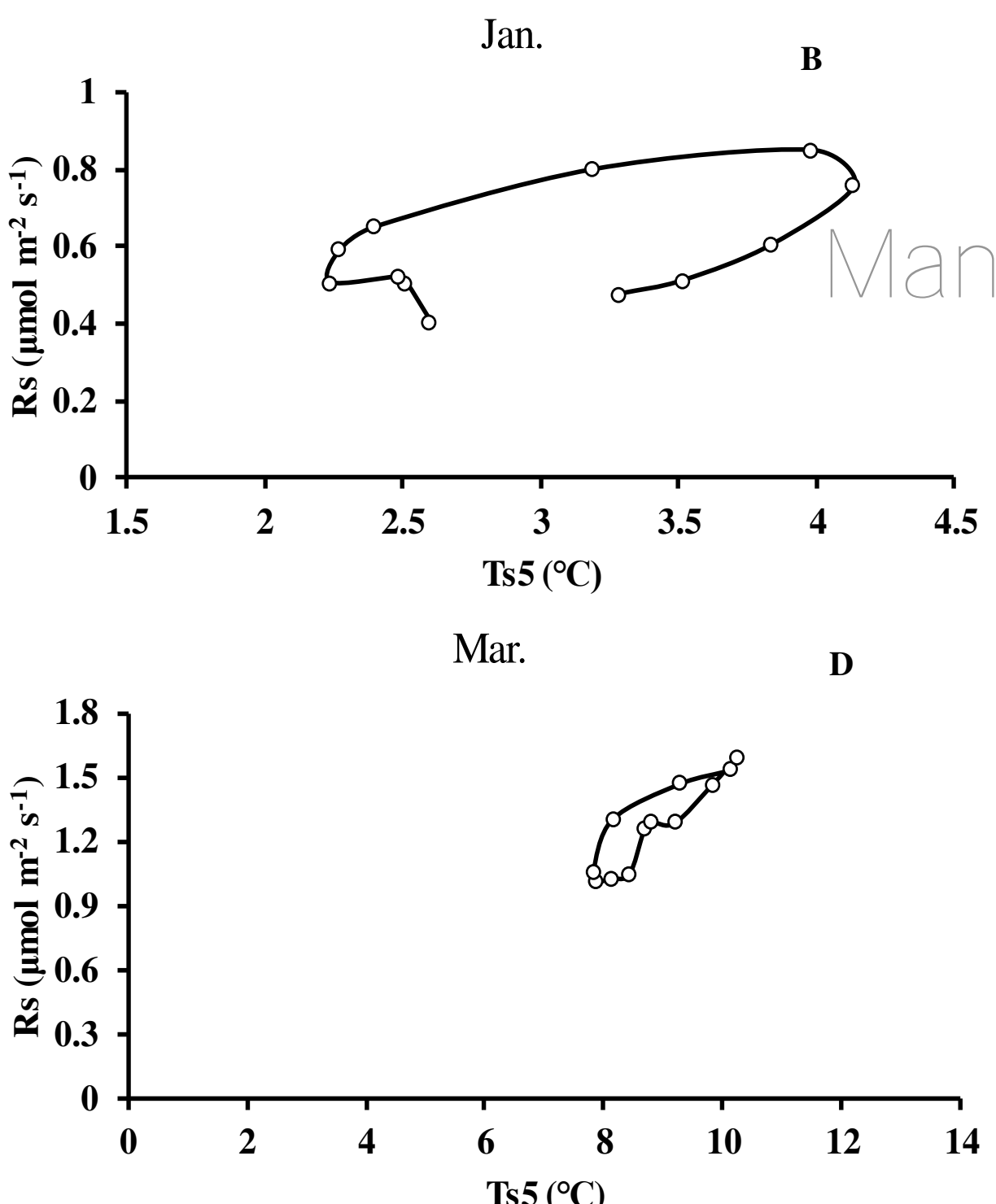

Jun.

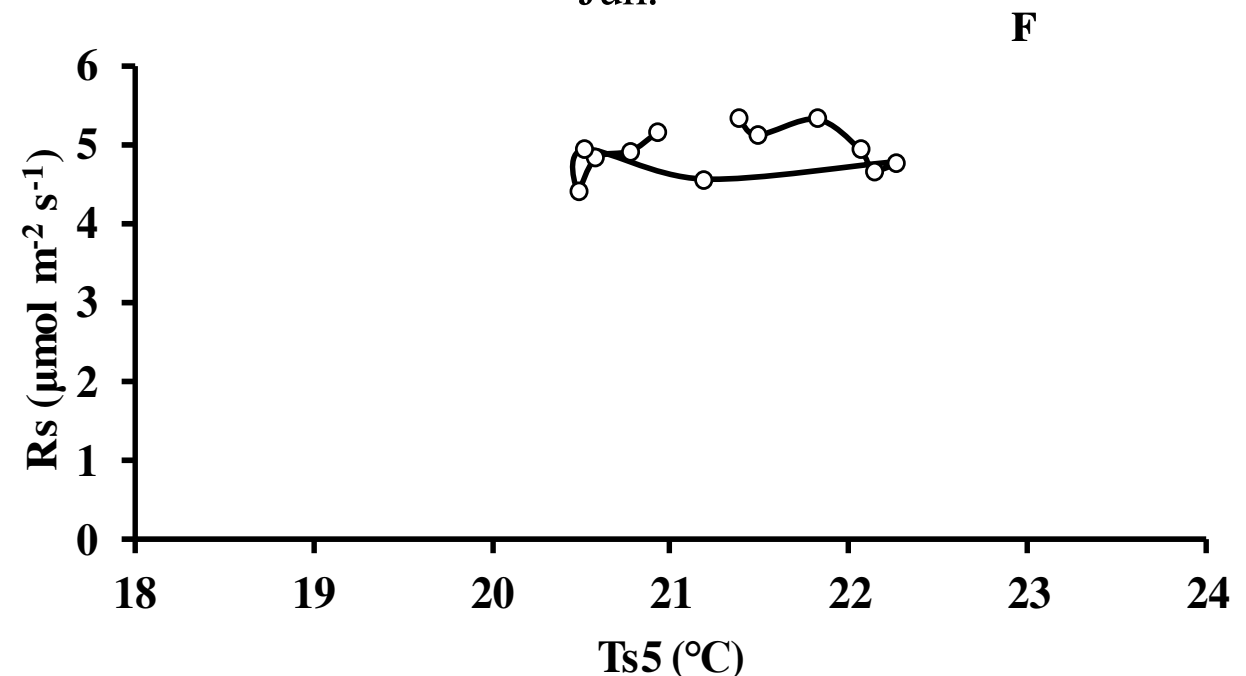

Sep.

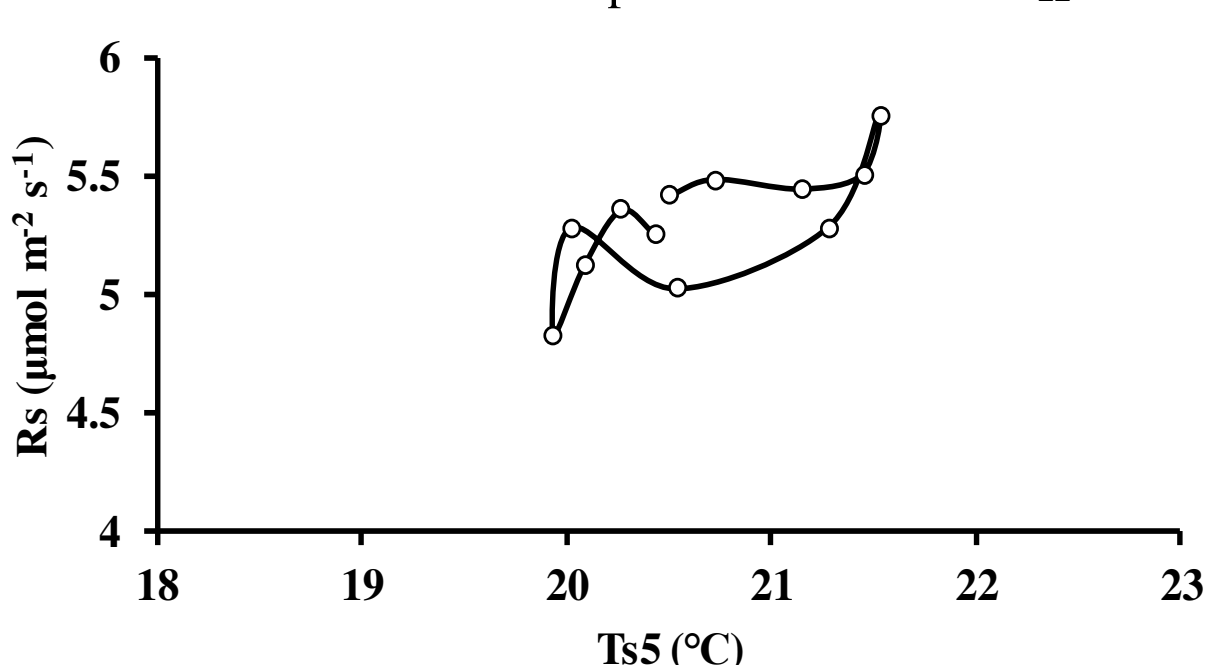




\section{Figure $\mathbf{5}$ (on next page)}

Relationship between monthly soil respiration and leaf area index ,gross ecosystem productivity.

(A) Residuals of observed minus predicted (calculated by the best model in the last row of Table 3) values of $R_{s}$ in relation to monthly values of LAl . monthly $R_{s}$ in relation to (B) mean monthly soil temperature, (C) LAI, and (D) monthly GEP .Black circles denote GEP of July and August, hollow circles are months excluding July and August; Dotted line is relationship including all the months in 2013, whereas solid line is excluding Rs of July and August. 

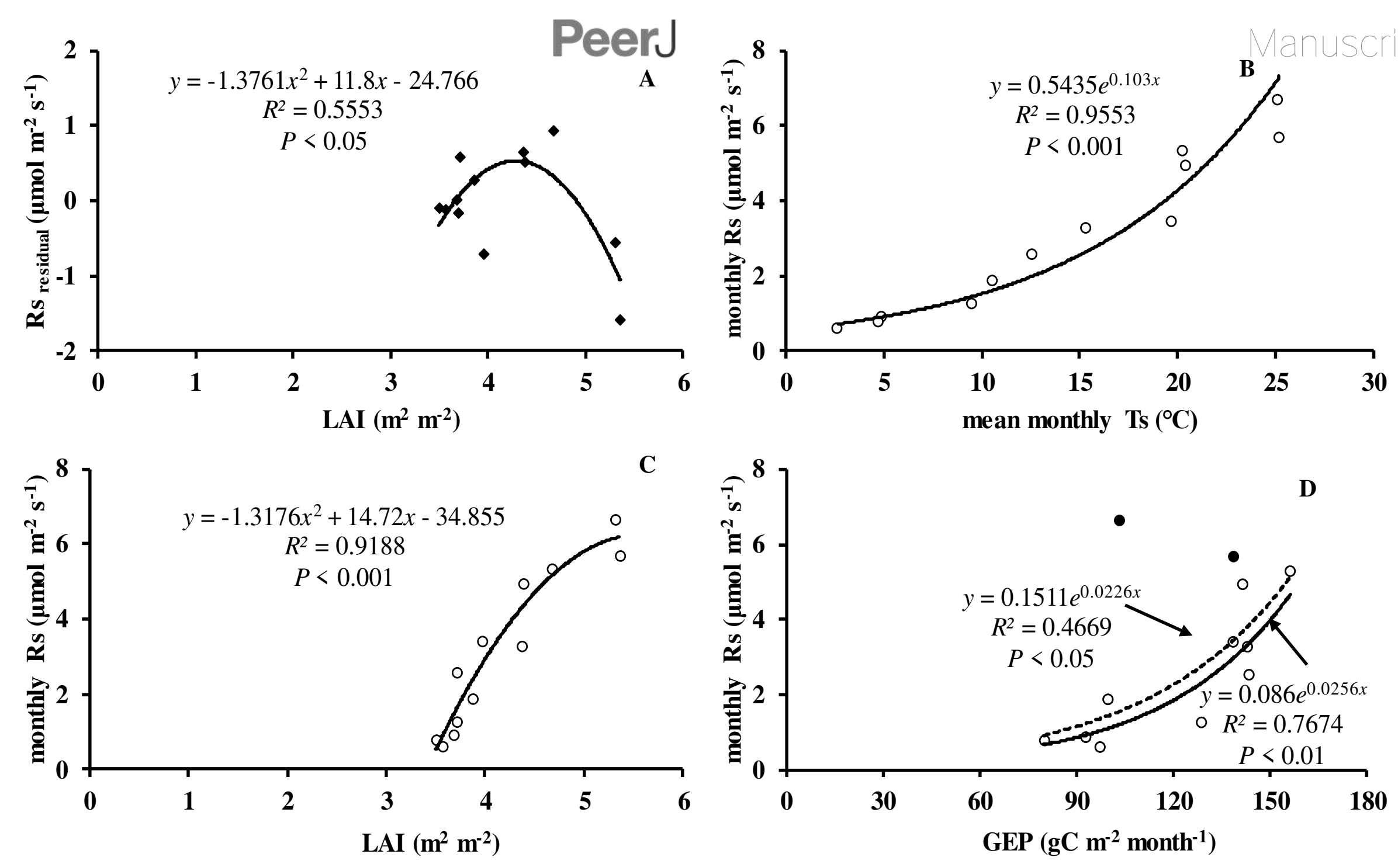


\section{Table $\mathbf{1}$ (on next page)}

Relationships between mean diurnal soil respiration $\left(R_{s}\right)$ and soil temperature measured by $L i-8150\left(T_{s}\right)$ in 2013.

Rs is soil respiration, Ts is soil temperature measured by Li-8150. 
1 Table. 1. Relationships between soil respiration $\left(\mathrm{R}_{\mathrm{s}}\right)$ and soil temperature measured by Li-8150 $2\left(\mathrm{~T}_{\mathrm{s}}\right)$.

3

\begin{tabular}{|c|c|c|c|c|c|}
\hline Time & Equation & $R^{2}$ & $Q_{10}$ & $\boldsymbol{F}$ & $P$ \\
\hline Dec. $\sim$ Feb. & $R_{s}=0.279 \exp \left(0.241 * \mathrm{~T}_{\mathrm{s}}\right)$ & 0.684 & 11.08 & 73.74 & 0.000 \\
\hline Mar. May & $R_{s}=0.629 \exp \left(0.095 * \mathrm{~T}_{\mathrm{s}}\right)$ & 0.819 & 2.59 & 154.39 & 0.000 \\
\hline Jun. $\sim$ Aug. & $R_{s}=1.427 \exp \left(0.058 * \mathrm{~T}_{\mathrm{s}}\right)$ & 0.627 & 1.79 & 57.08 & 0.000 \\
\hline Sep. $\sim$ Nov. & $R_{S}=0.594 \exp \left(0.107 * \mathrm{~T}_{\mathrm{s}}\right)$ & 0.983 & 2.92 & 1976.33 & 0.000 \\
\hline
\end{tabular}

4

5 


\section{Table 2 (on next page)}

Correlation coefficients of monthly mean soil $\mathrm{CO}_{2}$ fluxes and its affecting factors in 2013.

$T_{s}$ (soil temperature measured by Li-8150 probe), $R_{h}$ (air relative humidity measured by flux tower at $1 \mathrm{~m}$ height), GEP (gross ecosystem productivity), other variables shown see Figure 2 . Statistical significance with: ** p-values $<0.01, *$ p-values $<0.05$, besides, due to no significant correlation between soil moisture and other factors, it was not shown in Table 1 (expect GEP in July and August). 
1 Table 2. Correlation coefficients of monthly mean soil $\mathrm{CO}_{2}$ fluxes and its affecting factors in 22013.

\begin{tabular}{|c|c|c|c|c|c|c|c|c|c|}
\hline \multirow[t]{2}{*}{ Factors } & \multirow[t]{2}{*}{$\mathbf{R}_{\mathrm{s}}$} & \multicolumn{7}{|c|}{ Environmental } & \multirow[t]{2}{*}{ GEP } \\
\hline & & $\mathbf{T}_{\mathbf{s}}$ & $\mathbf{T}_{\mathrm{s} 5}$ & $\mathbf{T}_{\mathrm{s50}}$ & $\mathbf{T}_{\mathbf{a}}$ & $\mathbf{R h}$ & $\mathrm{SWC}_{5}$ & $\mathrm{SWC}_{50}$ & \\
\hline $\mathrm{T}_{\mathrm{s}}$ & $0.988^{* *}$ & & & & & & & & \\
\hline $\mathrm{T}_{\mathrm{s} 5}$ & $0.968^{* *}$ & $0.99^{* *}$ & & & & & & & \\
\hline $\mathrm{T}_{\mathrm{s} 50}$ & $0.966^{* *}$ & $0.95^{* *}$ & $0.97^{* *}$ & & & & & & \\
\hline $\mathrm{T}_{\mathrm{a}}$ & $0.966^{* *}$ & $0.99^{* *}$ & $0.99^{* *}$ & $0.946^{* *}$ & & & & & \\
\hline $\mathrm{Rh}$ & 0.21 & 0.21 & 0.152 & 0.133 & 0.081 & & & & \\
\hline $\mathrm{SWC}_{5}$ & -0.229 & -0.135 & -0.153 & -0.348 & 0.337 & 0.438 & & & \\
\hline $\mathrm{SWC}_{50}$ & 0.244 & 0.306 & 0.296 & 0.142 & 0.334 & $0.688^{*}$ & $0.813^{*}$ & & \\
\hline GEP & $0.841^{* *}$ & $0.868^{* *}$ & $0.863^{* *}$ & $0.752^{*}$ & $0.894^{* *}$ & 0.198 & 0.148 & 0.555 & \\
\hline LAI & $0.937^{* *}$ & $0.89^{* *}$ & $0.91^{* *}$ & $0.914^{* *}$ & $0.901^{* *}$ & 0.15 & -0.275 & 0.162 & $0.761^{*}$ \\
\hline
\end{tabular}

3

5

6 


\section{Table 3(on next page)}

Relationship between $\mathrm{R}_{s^{\prime}}, \mathrm{T}_{\mathrm{s}}$ and SWC. Coefficients of determination $\left(R^{2}\right)$ and root mean square error (RMSE) were given

The abbreviation was shown in Figure. 1. $P$ value of every model was 0.000 . 
Table 3. Relationship between $\mathrm{R}_{\mathrm{s}}, \mathrm{T}_{\mathrm{s}}$ and SWC. Coefficients of determination $\left(R^{2}\right)$ and root mean square error $(R M S E)$ were given.

\begin{tabular}{|c|c|c|c|c|c|c|c|}
\hline Model & References & $\boldsymbol{R}^{2}$ & $a$ & $b$ & $c$ & $d$ & $R M S E$ \\
\hline$R_{s}=\exp \left(\mathrm{a}+\mathrm{b} * \mathrm{~T}_{\mathrm{s}}\right) * \mathrm{SWC}$ & $(\mathrm{Gao}, 2011)$ & 0.895 & 1.07 & 0.09 & - & - & 0.663 \\
\hline$R_{S}=(\mathrm{c} * \mathrm{SWC}+\mathrm{d}) * \mathrm{a} * \exp \left(\mathrm{b} * \mathrm{~T}_{\mathrm{s}}\right)$ & (Han et al., 2008) & 0.918 & 0.64 & 0.08 & 1.13 & 0.97 & 0.591 \\
\hline$R_{s}=\exp \left(\mathrm{a}+\mathrm{b} * \mathrm{~T}_{\mathrm{s}}+\mathrm{c} * \mathrm{SWC}+\mathrm{d} * \mathrm{~T}_{\mathrm{s}} * \mathrm{SWC}\right)$ & (Li et al., 2000) & 0.919 & 0.22 & 0.05 & -1.97 & 0.14 & 0.588 \\
\hline$R_{s}=\exp \left(\mathrm{a}+\mathrm{b}^{*} \mathrm{~T}_{\mathrm{s}}+\mathrm{c} * \mathrm{SWC}+\mathrm{d}^{*} \mathrm{SWC} \mathrm{C}^{2}\right)$ & (Tang and Baldocchi, 2005) & 0.922 & 1.88 & 0.08 & -18 & 39 & 0.578 \\
\hline$R_{s}=\mathrm{a}+\mathrm{b}^{*} \mathrm{~T}_{\mathrm{s}}+\mathrm{c} * \mathrm{SWC}+\mathrm{d}^{*} \mathrm{~T}_{\mathrm{s}} * \mathrm{SWC}$ & (Wang et al., 2003) & 0.929 & -3.74 & 0.47 & 13.45 & -0.9 & 0.542 \\
\hline$R_{s}=\mathrm{a}+\mathrm{b} * \exp \left(\mathrm{c}^{*} \mathrm{~T}_{\mathrm{s}}\right)+\mathrm{d}^{*} \mathrm{~T}_{\mathrm{s}} * \mathrm{SWC}$ & (Zhou et al., 2008) & 0.936 & -4.73 & 4.76 & 0.03 & -0.04 & 0.515 \\
\hline
\end{tabular}

4 Note: the abbreviation was shown in Figure. 1. P value of every model was 0.000. 